\title{
PERBEDAAN PENGARUH METODE LATIHAN FARTLEK DAN INTERVAL TERHADAP DAYA TAHAN (ENDURANCE)
}

\author{
Taufik Nanda Aditiya ${ }^{(1)}$, Waluyo $^{(2)}$, Ahmad Septiandika Adirahma ${ }^{(3)}$ \\ (1) (2) (3) Universitas Sebelas Maret Surakarta
}

\begin{abstract}
The purpose of this study is to determine: (1) To test whether there is influence of the application of fartlek and interval training methods to endurance in extracurricular students futsal SHS 3 Sukoharjo 2016/2017, (2) More effective and efficient between fartlek and interval training on Endurance in extracurricular students of SHS 3 Sukoharjo year 2016/2017.

The type of research used is quantitative experimental research. Subjects used in this study are extracurricular students futsal SHS 3 Sukoharjo 2016/2017. The number of learners is 30 students. The entire subject is used as the research sample. The data collected in this research is Endurance data about VO2 Max capacity. The tests and measurements used to collect data are by performing the Multistage Fitness Test (MFT) test. The data analysis technique used in this research is the difference test (t-test) by passing the first requirement test such as normality test and homogeneity test.

The result of the study was: (1) There was a significant comparison of the effects of fartlex training method and interval training on energency participants in futsal extracurricular leaners of SHS 3 SUKOHARJO year 2016/2017, ( $t$ count $=2,6651>1,7613)$; (2) Interval training methods better than fartlek training method for energency participants in futsal extracurricular leaners of SHS 3 SUKOHARJO year 2016/2017. Based on the precentage increase of physical endurance showed that group 2 (who received treatment with interval training method was 5,64\% > group 1 (who received treatment fartlek training method) was 2,62\%.

The conclude of the result as: (1) There was a comparison of the effects of fartlex training method and interval training on energency participants in futsal extracurricular leaners of SHS 3 SUKOHARJO year 2016/2017; (2) Interval training method better than fartlek training method on the physical endurance of extracurricular learners SHS 3 SUKOHARJO year 2016/2017.
\end{abstract}

Keywords: Futsal, Fartlek, Interval, Energency Participants. 


\section{PENDAHULUAN}

Olahraga merupakan kegiatan untuk menjaga dan meningkatkan kebugaran tubuh. Olahraga adalah aktivitas fisik untuk melatih tubuh seseorang. Tidak hanya secara jasmani tetapi juga secara rohani. Olahraga pada hakikatnya adalah proses pendidikan yang memanfaatkan aktifitas fisik yang untuk menghasilkan perubahan holistic dalam kualitas individu, baik dalam hal fisik, mental serta emosional. Utamanya olahraga berfungsi untuk menyehatkan badan dan memastikan organ tubuh masih sehat, secara garis besar olahraga merupakan aktivitas fisik yang penting dilakukan dalam keseharian, baik dalam gerakan terarah (cabang olahraga) ataupun gerakan lainnya.

Futsal adalah permainan bola yang dimainkan oleh dua tim, yang masing-masing beranggotakan lima orang. Tujuannya adalah memasukkan bola ke gawang lawan, dengan memanipulasi bola dengan kaki. Selain lima pemain utama, setiap regu juga diizinkan memiliki pemain cadangan. Futsal di Indonesia saat ini sudah sangat berkembang. Akan tetapi, sampai saat ini olahraga futsal hanya bersifat rekreatif saja, belum menjadi sebuah olahraga profesional. Sekarang tinggal bagaimana Badan Futsal Nasional (BFN) dan Persatuan Sepak bola Seluruh Indonesia (PSSI) dapat bekerja bahu-membahu untuk membawa olahraga ini dinikmati semua masyarakat dan menjadi sebuah olahraga yang profesional.

Futsal menjadi olahraga yang paling digemari oleh masyarakat Indonesia. Hal ini dapat dibuktikan dari jumlah lapangan futsal yang semakin tahun semakin bertambah jumlahnya. Tetapi dengan bertambahnya jumlah lapangan futsal tersebut justru semakin bertambah pula orang-orang yang bermain futsal. Hal ini dapat di cek dari jadwal di setiap lapangan futsal yang tidak pernah kosong. Dari anak-anak, remaja, dan orang dewasa sangat gemar memainkan olahraga ini. Untuk orang dewasa memilih olahraga futsal sebagai olahraga rekreasi ketika mengisi waktu luang. Tetapi untuk anak 
muda, sebagian dari mereka menjadikan olahraga ini sebagai olahraga prestasi. Khususnya bagi pelajar terutama pelajar SMA. Futsal ditingkat pelajar SMA sekarang telah di jadikan pertimbangan dan menjadi magnet untuk memikat peserta didik baru yang berkualitas dari jenjang SMP yang ingin melanjutkan sekolahnya ditingkat SMA. Hal ini terjadi karena di Era sekarang ini telah banyak sekali kejuaraan-kejuaraan futsal Nasional yang besar, contohnya Kejuaraan yang diadakan oleh Pocary Sweat dan Hydrococo. Kejuaraan tersebut adalah kejuaraan Nasional yang lingkupnya bisa sampai Internasional kalau bisa menjadi juara 1 Nasional. Mereka yang bisa menjadi Juara 1 di tingkat Nasional dapat mewakili Indonesia di Kejuaraan Internasional yang diadakan di Thailand setiap tahunnya. Jadi, itu merupakan contoh kecil bagi perkembangan futsal di tingkat pelajar SMA dan alasan kenapa sekarang banyak SMA yang ingin membangun peserta didiknya tidak hanya bermutu di bidang akademik tapi juga bidang non-akademik juga sama-sama di perhatikan. Bahkan ada SMA yang justru mengedepankan bidang nonakademik karena futsal, hal ini karena mereka ingin popularitas SMA mereka bisa terangkat melalui prestasi di bidang non-akademik yaitu dari futsal.

Penguasaan kondisi fisik merupakan kelengkapan yang paling mendasar, tanpa mengesampingkan unsur yang lain seperti penguasaan teknik, taktik dan mental. Untuk mencapai prestasi dalam futsal, maka kondisi fisik atau daya tahan (endurance) haruslah baik. Endurance atau daya tahan adalah kemampuan seseorang melaksanakan gerak dengan seluruh tubuhnya dalam waktu yang cukup lama dan dengan tempo sedang sampai cepat tanpa mengalami rasa sakit dan kelelahan berat. Kemampuan otot untuk melakukan kerja terus-menerus adalah sangat penting dalam aktivitas olahraga karena secara tidak langsung merupakan daya untuk dapat mengatasi kelelahan otot. Untuk 
mengetahui kualitas daya tahan (endurance) bisa dilakukan dengan menggunakan tes, yaitu antara lain: tes lari $2400 \mathrm{~km}$, tes lari $4800 \mathrm{~m}$, dan tes lari multitahap (Multystage Fitness Test). Tetapi untuk lebih sesuainya, tes yang sebaiknya dipakai yaitu tes lari multitahap (Multystage Fitness Test). Hal ini karena olahraga futsal pergerakan dan kebutuhan energinya tidak berbeda jauh dengan tes lari multitahap (Multystage Fitness Test).

Latihan daya tahan akan mengembangkan konsumsi oksigen. Faktor utama keberhasilan dalam latihan dan pertandingan olahraga futsal dipengaruhi oleh tingkat kemampuan ketahanan olahragawan. Jadi, kemampuan ketahanan seseorang yang baik akan mampu melakukan pekerjaannya dengan maksimal. Maka dari itu perlu adanya latihan fisik. Metode latihan yang bisa meningkatkan daya tahan mereka yaitu, fartlek dan interval.

Latihan fartlek adalah lari lambat-lambat yang kemudian divariasikan dengan sprint-sprint pendek yang intensif dari lari jarak menengah hingga kecepatan konstan yang cukup tinggi kemudian diselingi dengan lari sprint dan jogging dan sprint lagi seterusnya. Jadi, variasi tempo lari bisa di main-mainkan sesuai kondisi atlet. Dalam latihan ini para atlet melakukan lari dengan kecepatan bervariasi, mulai dari kecepatan rendah sampai hanya melakukan jogging. Pada prinsipnya tergantung kepada kemauan atlet sendiri. Sehingga latihan fartlek dapat dikatakan latihan bebas, baik jarak maupun kecepatan bukan merupakan tujuan utama. Walaupun para atlet bebas dalam melaksanakan latihannya, tetapi secara periodik mereka harus mencapai tingkat intensitas yang tinggi pula. Latihan fartlek ini bertujuan memelihara, membangun, dan mempertahankan kondisi fisik seorang atlet.

Latihan interval adalah suatu sistem latihan yang diselingi oleh interval-interval yang berupa masamasa istirahat. Interval training sangat dianjurkan oleh pelatihpelatih terkenal oleh karena 
hasilnya memang sangat positif bagi perkembangan daya tahan maupun stamina atlet. Latihan fisik yang diulang-ulang dengan diselingi waktu atau periodeperiode pemulihan. Hampir semua latihannya dihitung waktunya, sehingga atlet merasakan bagaimana lari pada tempo tertentu. Secara biologis latihan interval merangsang perbaikan pengambilan oksigen maksimum $\left(\mathrm{VO}_{2}\right.$ max $)$ karena peningkatan densitas mitokondria dalam sel otot. Oleh karena itu latihan interval sangat baik dalam membina daya tahan dan stamina, maka jenis latihan ini dapat diterapkan pada cabang olahraga seperti sepak bola, futsal, bola basket, dan olahraga lainnya yang menurut para ahli fisiologis yang berpendapat bahwa latihan endurance sangatlah penting bagi semua cabang olahraga.

Daya tahan merupakan faktor fisik yang sangat penting dalam olahraga futsal dan merupakan faktor yang menentukan prestasi, karena daya tahan yang baik dari seorang atlet akan mampu menerapkan teknik dan taktik secara maksimal, sehingga dengan kemampuan daya tahan yang prima kesempatan untuk meraih prestasi akan lebih mudah. Hal ini yang dialami peserta didik ekstrakurikuler futsal SMA Negeri 3 Sukoharjo, mereka belum bisa berprestasi di lapangan futsal berstandar Internasional karena faktor daya tahan (endurance) mereka yang masih lemah. Untuk mengatasi masalah tersebut penulis berusaha untuk meneliti metode latihan yang efektif dan efisien untuk meningkatkan daya tahan (endurance).

\section{Tujuan Penelitian}

Berdasarkan masalah yang telah di rumuskan di atas, penelitain ini memiliki tujuan untuk mengetahui:

1. Untuk menguji ada tidaknya pengaruh penerapan metode latihan fartlek dan interval terhadap daya tahan (endurance).

2. Latihan yang lebih efektif dan efisien antara latihan fartlek dan interval terhadap daya tahan (endurance) . 


\section{KAJIAN PUSTAKA}

\section{Futsal}

Futsal merupakan jenis permainan yang dimainkan dengan segala aspek yang lebih sederhana dibandingkan sepak bola. Futsal dapat dimainkan di lapangan yang ukurannya lebih kecil dari lapangan sepak bola dan dengan jumlah pemain yang lebih sedikit dari masing-masing tim. Futsal merupakan satu di antara sekian banyak permainan yang digemari oleh penduduk di seluruh belahan dunia. Ada keasyikan tersendiri yang di rasakan oleh mereka yang memainkan olahraga jenis bola besar ini. Selain mampu menciptakan suasana kebersamaan antar individu dalam satu tim, olahraga ini pun mampu menciptakan suasana antar tim yang bertanding. Secara umum, futsal dapat diartikan sebagai suatu permainan olahraga yang dimainkan oleh dua tim yang berbeda. Masing-masing tim beranggotakan lima orang pemain yang memainkan pertandingan dalam dua babak. Olahraga futsal ditujukan untuk membentuk perpaduan individu-individu pemain yang tergabung dalam sebuah tim demi mencapai kemenangan. Kebersamaan dan kerjasama tim sangat diperlukan dalam mencapai tujuan tersebut (Muhammad Asriady Mulyono, 2014: 1-2).

Futsal adalah jenis permainan yang tidak jauh berbeda dengan sepak bola. Inti permainannya adalah menyepak bola ke sana kemari, memperebutkan bola antar pemain dengan tujuan memasukkan bola ke gawang lawan atau mempertahankan gawang sendiri agar tidak kemasukkan bola (A. Handoyo, 2010: 1).

Futsal adalah permainan yang sangat cepat dan dinamis. Dari segi lapangan yang relatif kecil, hampir tidak ada ruangan untuk membuat kesalahan. Oleh karena itu diperlukan kerjasama antar pemain lewat passing yang akurat, bukan hanya untuk melewati lawan. Futsal adalah olahraga beregu. Kolektivitas tinggi akan mengangkat prestasi (Justinus Lhaksana, 2011: 7). 
Dari pendapat diatas dapat disimpulkan bahwa permainan futsal adalah suatu permainan olahraga yang dimainkan oleh dua tim yang berbeda dengan masingmasing tim beranggotakan lima orang pemain yang memainkan pertandingan dalam dua babak dengan tujuan memasukkan bola sebanyak-banyaknya ke gawang lawan. Dalam permainan futsal dimainkan dalam dua babak dan masing-masing babak memiliki durasi waktu 20 menit dengan waktu istirahat 10 menit. Permainan futsal dipimpin oleh 2 orang wasit yang bertugas di sisi lapangan dan tidak ada hakim garis karena 2 wasit yang bertugas di lapangan semuanya mempunyai wewenang untuk menjalankan pertandingan di sisi yang berlawanan. Kedua wasit di lapangan tersebut akan dibantu oleh wasit ketiga yang bertugas sebagai pencatat waktu di sisi luar pertengahan lapangan atau tepatnya di antara area pergantian pemain kedua regu yang bertanding.

\section{Latihan Fisik}

Latihan fisik adalah meningkatkan kualitas sistem otot dan kualitas sistem energi yakni dengan melatih unsur gerak atau biomotor (Djoko Pekik, 2002: 65).

Menurut Andi Suhendro dkk (2003: 4.1) latihan fisik adalah latihan yang ditujukan untuk mengembangkan dan meningkatkan kondisi seseorang. Latihan ini mencakup semua komponen kondisi fisik antara lain kekuatan otot, daya tahan kardiovaskuler, daya tahan otot, kelincahan, kecepatan, kekuatan, stamina, kelentukan dan lain-lain.

Di dalam masalah metode latihan kondisi fisik, dapat dibedakan menjadi dua macam program latihan. Pertama program latihan peningkatan kondisi fisik, baik perkomponen maupun secara keseluruhan. Hal ini dilaksanakan bila berdasarkan tes awal, olahragawan yang bersangkutan belum berada dalam status kondisi fisik yang diperlukan untuk pertandingan-pertandingan yang akan dilakukannya. Yang kedua adalah program latihan 
mempertahankan kondisi fisik, yaitu suatu program latihan yang disusun sedemikian rupa sehingga dengan program tersebut diharapkan akan berada dalam status kondisi puncak sesuai dengan kondisi fisik yang dibutuhkan untuk cabang olahraga yang bersangkutan dalam suatu turnamen atau pertandingan-pertandingan tertentu (M. Sajoto, 1995: 29).

\section{Daya Tahan (Endurance) dan} Sistem Cardiovascular

Daya tahan adalah kemampuan seseorang melakukan aktivitas fisik berupa gerakan yang berulang-ulang dalam waktu lama dan ditentukan oleh kapasitas kerja sistem jantung, peredaran darah untuk menyalurkan oksigen ke otototot yang sedang aktif dan kapasitas paru-paru mengambil oksigen dan mengeluarkan karbondioksida sehingga kebutuhan oksigen cukup untuk pembakaran karbohidrat yang menghasilkan energi sesuai kebutuhan gerak yang dilaksanakan (Andi Suhendro, dkk. 2003: 4.35).
Menurut Neiman (1986)

dalam Justinus Lhaksana (2011: 21) Daya tahan (endurance) adalah kemampuan seseorang bekerja dalam waktu lama karena adanya jaminan kerja otot, yaitu dengan mengambil oksigen dan menyalurkan otot yang aktif.

Daya tahan adalah kemampuan kondisi tubuh untuk melakukan kerja dalam waktu yang lama. Endurance atau daya tahan dapat dibagi dalam dua macam yaitu, daya tahan umum (general endurance) dan daya tahan otot (local endurance). Yang pertama daya tahan umum (general endurance) yaitu kemampuan seseorang dalam mempergunakan sistem jantung, paru-paru dan peredaran darahnya secara efektif dan efisien untuk menjalankan kerja secara terus menerus yang melibatkan kontraksi sejumlah otototot dengan intensitas tinggi dalam waktu yang cukup lama. Yang Kedua adalah daya tahan otot setempat atau muscular endurance (local endurance), yaitu kemampuan seseorang mempergunakan ototnya untuk 
berkontraksi secara terus menerus dalam waktu yang relatif lama dengan beban tertentu. Endurance adalah kemampuan seseorang melaksanakan gerak dengan seluruh tubuhnya dalam waktu yang cukup lama dan dengan tempo sedang sampai cepat tanpa mengalami rasa sakit dan kelelahan berat. Sedangkan yang dimaksud dengan latihan endurance pada umumnya adalah Cardiorespiratory endurance, yaitu latihan yang bertujuan untuk meningkatkan kemampuan seluruh tubuh untuk selalu bergerak dalam tempo sedang sampai cepat yang cukup lama (M. Sajoto, 1995: 121).

\section{Latihan Untuk Meningkatkan} Daya Tahan (Endurance)

Latihan daya tahan akan mengembangakan konsumsi oksigen. Menurut Andi Suhendro, dkk (2003: 5.6) "Daya tahan adalah kemampuan seseorang terhadap kelelahan”. Daya tahan merupakan unsur dasar dari kesegaran fisik. Prestasi atlet akan terhambat kemajuanya jika daya tahannya tidak cukup terlatih. Seseorang yang yang mempunyai daya tahan tinggi dapat melakukan aktivitas yang lebih lama secara terus menerus. Peniningkatan daya tahan dapat menunda timbulnya kelelahan. Nilai $\mathrm{VO}_{2}$ max yang tinggi dapat meningkatkan unjuk kerja pada aktivitas daya tahan, yaitu meningkatkan kemampuan rata-rata kerja lebih besar atau lebih cepat.

Kiranya perlu dikemukakan sekali lagi bahwa semua latihan lari dengan berbagai variasinya, bersepeda dan berenang merupakan latihan endurance. Menurut $\mathrm{M}$. Sajoto (1995: 140), Berikut adalah contoh latihan endurance khususnya adalah latihan-latihan lari, karena lari sangat sederhana dan mudah pelaksanaannya. Berikut adalah metode latihan untuk meningkatkan daya tahan, yaitu: 1) Interval Training, 2) Latihan Lari Jarak Jauh, 3) Fartlek / Speed Play, dan 4) Interval Circuit Training.

Interval training atau latihan berselang adalah latihan yang bercirikan adanya interval kerja diselingi interval istirahat 
(recovery). Latihan interval biasanya menggunakan intensitas tinggi, yaitu $80-90 \%$ dari kemampuan maksimal. Waktu (durasi) yang digunakan antara 2 5 menit. Lama istirahat antara 2-8 menit. Perbandingan latihan dengan istirahat adalah 1:1 atau 1:2. Repetition (ulangan) 3-12 kali.

Latihan lari jarak jauh adalah latihan berlari dengan kecepatan dan jarak yang ditentukan, tanpa waktu istirahat sampai seluruh jarak ditempuh. Menurut Fox dan Menthews yang dikutip oleh $\mathrm{M}$. Sajoto (1995: 141), lari jarak jauh di bagi menjadi dua cara, masingmasing adalah Continous SlowRunning dan Continous FastRunning.

Fartlek / Speed Play adalah program interval training yang tidak formal. Di dalam latihan ini termasuk fast dan slow running yang bergantian. Namun demikian banyak para pelatih dan para atlet memasukkan program latihan tersebut, sebagai variasai latihan lari dalam intesitas tinggi dan variasi latihan interval. Walaupun para atlet bebas dalam melaksanakan latihannya, tetapi secara periodik mereka harus mencapai tingkat intensitas yang tinggi pula (M. Sajoto, 1995: 142).

Interval-Circuit Training dirancang selain untuk mengembangkan kapasitas paru, juga untuk mengembangkan kekuatan otot. Konsep latihan ini adalah penggabungan latihan interval dan circuit training. Circuit training merupakan bentuk latihan yang terdiri dari beberapa pos (station) latihan yang dilakukan secara berurutan dari pos satu sampai pos terakhir. Jumlah pos antara 8-16. Istirahat dilakukan pada jeda antara pos satu dengan pos yang lainnya. Agar program latihan dapat berjalan sesuai tujuan maka latihan harus diprogram sesuai dengan prinsip-prinsip latihan yang benar. Jarak circuit kira-kira satu sampai lima mil, dengan pos setiap jarak 400-1600 yard. Para atlet melakukan jogging atau sprint di antara pos, kemudian berhenti di setiap pos untuk melakukan latihan kekuatan, fleksibilitas, atau melakukan latihan endurance otot dengan cara seperti pada circuit 
training biasa, dan kemudian melanjutkan jogging atau sprint, menuju ke pos berikutnya (M. Sajoto, 1995: 142).

\section{Latihan Fartlek}

Menurut Fox dan Mathews dalam M. Sajoto (1995: 142), bahwa "Latihan fartlek adalah program interval training yang tidak formal". Bentuk latihan fartlek ini diperkenalkan pertama kali di Swedia pada tahun 1930-an dan dilakukan oleh para pelari jarak jauh. Latihan fartlek ini disebut juga dengan istilah speed play. Sistem latihan fartlek atau speed play diciptakan oleh Gotta Roamer yang berasal dari Swedia. Sedangkan menurut Harsono (1988: 156) bahwa, "fartlek adalah lari lambat-lambat yang kemudian divariasikan dengan sprint-sprint pendek yang intensif dari lari jarak menengah hingga kecepatan konstan yang cukup tinggi kemudian diselingi dengan lari sprint dan jogging dan sprint lagi seterusnya. Jadi, variasi tempo lari bisa di main-mainkan sesuai kondisi atlet."
Dalam latihan ini para atlet melakukan lari dengan kecepatan bervariasi, mulai dari kecepatan rendah sampai hanya melakukan jogging.

Pada prinsipnya tergantung kepada kemauan atlet sendiri. Sehingga latihan fartlek dapat dikatakan latihan bebas, baik jarak maupun kecepatan bukan merupakan tujuan utama. Namun walaupun demikian banyak para pelatih dan para atlet memasukkan program latihan fartlek tersebut sebagai variasi latihan lari intensitas tinggi dan variasi latihan interval. Walaupun para atlet bebas dalam melaksanakan latihannya, tetapi secara periodik mereka harus mencapai tingkat intensitas yang tinggi pula.

Latihan fartlek ini bertujuan memelihara, membangun, dan mempertahankan kondisi fisik seorang atlet. Latihan ini biasanya diprogramkan sebelum pertandingan karena latihan ini tujuan utamanya adalah kegembiraan sehingga diharapkan bentuk latihan ini dapat mengurangi kejenuhan sebelum pertandingan. 
Dari tujuan latihan fartlek ini sebaiknya latihan dilakukan di alam terbuka yang terdapat bukit-bukit semak belukar, selokan-selokan untuk dilompati, tanah berpasir, tanah rumput, tanah lembek, dan sebagainya. Fartlek juga dapat dilakukan di jalan umum, lapangan ataupun lintasan atletik.

Fartlek biasanya dimulai dengan lari-lari kecil lambat yang kemudian divariasi sprint-sprint yang cukup tinggi. Variasi tempo lari ini bisa dimainkan oleh atlet tergantung dari kondisi atlet apabila terasa lelah boleh lari pelan-pelan bahkan boleh berjalan. Dan setelah merasa kuat lagi bisa lari lagi atau sprint. Hal ini sesuai dengan yang dikemukakan Sudjarwo (1995: 37), bahwa "Waktu latihan ini tidak dibatasi akan tetapi atlet bebas melakukan latihan dengan berbagai variasi bentuk lari sesuai dengan medannya". Oleh karena itu, sistem latihan ini disebut dengan fartlek yang artinya bermain-main dengan kecepatan.

Untuk mendapatkan hasil yang maksimal dari latihan fartlek seorang pelatih harus memperhatikan prinsip-prinsip latihan fartlek, yaitu antara lain:

1. Latihan fartlek latihan bebas dimana jarak dan waktu bukan tujuan utamanya sehingga atlet bebas untuk menentukan kecepatan larinya sesuai dengan kondisi fisik masing-masing.

2. Intensitas latihan harus ditingkatkan secara progresif dari satu waktu ke waktu yang berikutnya.

3. Istirahat yang digunakan adalah istirahat aktif seperti berjalan, jogging, dan berlari langkah panjang (striding).

4. Setelah istirahat aktif kemudian dimulai lagi lari dengan kecepatan lambat.

\section{Pelaksanaan Latihan Fartlek}

Pelatih ataupun atlet sendiri dapat menentukan bentuk lari maupun lamanya latihan. Menurut Costa Holmer dalam Sudjarwo (1995: 37) kecepatan bentuk latihan fartlek dapat diukur dengan variasi, misalnya:

1. Mulai dengan lari lambat 5-10 menit.

2. Kecepatan konstan dan cukup tinggi. 
3. Jalan cepat (istirahat aktif).

4. Lari lambat-lambat diselingi lari yang makin lama makin cepat (win sprint).

5. Lari lambat-lambat diselingi 3-4 langkah mendadak cepat.

6. Naik bukit dengan kecepatan tinggi.

7. Lari dengan tempo yang cepat selama 1 menit.

Satu sesi latihan fartlek lebih efektif maka akan menjadi jogging selama 90 detik, diikuti oleh langkah panjang selama 30 detik, diikuti dengan jogging selama 45 detik, kemudian diikuti oleh semua out sprint selama 30 detik, diikuti dengan berjalan selama 105 detik. Hal ini kemudian akan diulang untuk total 20-60 menit.

\section{Latihan Interval}

Latihan interval menurut Harsono (1988: 156-157) adalah suatu sistem latihan yang diselingi oleh interval-interval yang berupa masa-masa istirahat. Interval training sangat dianjurkan oleh pelatih-pelatih terkenal oleh karena hasilnya memang sangat positif bagi perkembangan daya tahan maupun stamina atlet. Latihan fisik yang diulang-ulang dengan diselingi waktu atau periodeperiode pemulihan.

Menurut Harsono (1988: 157) mengatakan, "Ada beberapa faktor yang harus dipenuhi dalam menyusun interval training, yaitu:

1. Lamanya latihan (duration).

2. Beban (intensitas) latihan.

3. Ulangan (repetition) melakukan latihan.

4. Masa istirahat (recovery internal) setiap repetisi latihan.

Lamanya latihan dapat diterjemahkan dengan jarak lari yang harus ditempuh, beban latihan dengan waktu (tempo) untuk jarak tersebut, ulangan latihan adalah beberapa kali jarak tersebut harus dilakukan, sedangkan yang dimaksud dengan masa istirahat diantara setiap ulangan hari.

Latihan interval merupakan penyempurnaan dari latihan fartlek dengan memberikan koreksi secara teliti dalam menentukan jarak, istirahat, repetisi, dan waktu latihan. Perlu diterangkan bahwa interval atau istirahat itu sangat penting untuk dapat mengembalikan kembali kebugaran 
atlet agar dapat melaksanakan latihan kembali. Ada dua hal penting yang harus diperoleh dari latihan interval. Yang Pertama, latihan interval merupakan adaptasi sistem syaraf terhadap pengalaman bentuk gerakan yang sesungguhnya terjadi dalam pertandingan. Yang kedua, latihan ini memberi kesempatan pada seseorang untuk berlatih dalam waktu yang lebih lama dengan intensitas yang jauh lebih tinggi namun pada batas aerobic.

Berdasarkan pada pernyataan-pernyataan diatas bahwa, latihan interval memberi pelajaran berharga kepada atlet khususnya belajar tentang tempo (pacing) menetapkan panjang langkah atau lebar dan banyak langkah per satuan waktu. Dengan latihan ini keterampilan kompetitif juga dilatih dan rangsangan terhadap kardiovaskuler dirangsang lebih tinggi dibandingkan dengan hanya berlari terus-menerus.

\section{Pelaksanaan Latihan Interval}

Dalam pelaksanaan latihan interval harus memperhatikan istilah-istilah berikut untuk menyusun program latihan: Set, Repetisi, Waktu Latihan, Jarak latihan, Frekuensi, dan Waktu istirahat antar repetisi serta antar set (M. Sajoto, 1995: 140).

\section{METODE PENELITIAN}

Metode penelitian yang digunakan adalah penelitian kuantitatif eksperimen. Subjek yang digunakan dalam penelitian ini adalah peserta didik adalah 30 . Data yang dikumpulkan pada penelitian ini berupa data daya tahan (endurance) mengenai kapasitas $\mathrm{VO}_{2}$ Max. Tes dan Pengukuran yang digunakan untuk mengumpulkan data adalah dengan melakukan tes Multystage Fitness Test (MFT). Teknik analisis data yang digunakan dalam penelitian ini adalah uji perbedan (uji-t) dengan melalui uji persyaratan terlebih dahulu seperti uji normalitas dan uji homogenitas.

\section{HASIL PENELITIAN}

1. Ada perbedaan pengaruh antara metode latihan fartlek dan interval terhadap daya tahan (endurance) terhadap peserta didik. 
Dari data yang diperoleh sebelum diberikan perlakuan, setelah dianalisis diperoleh nilai $\mathrm{t}$ antara tes awal pada kelompok I dan tes awal kelompok II $=0,4913$ sedangkan $\mathrm{t}_{\text {tabel }}=1,7613$. Berarti hipotesis nol diterima. Dengan demikian kelompok I dan kelompok II sebelum diberi perlakuan dalam keadaan seimbang. Antara kelompok I dan kelompok II berangkat dari titik tolak yang sama, yang berarti apabila setelah diberi perlakuan terdapat perbedaan, hal itu terjadi karena adanya perbedaan perlakuan yang diberikan.

Nilai t antara tes awal dan tes akhir pada kelompok $\mathrm{I}=4,8902$ sedangkan $\mathrm{t}$ tabel $=1,7613$. Berarti hipotesis nol ditolak, dengan demikian dapat disimpulkan bahwa terdapat perbedaan yang signifikan antara hasil tes awal dan tes akhir pada kelompok I. Nilai t antara tes awal dan tes akhir pada kelompok $\mathrm{II}=6,1503$ sedangkan $\mathrm{t}$ tabel $=$ 1,7613. Berarti hipotesis nol ditolak, dengan demikian dapat disimpulkan bahwa terdapat perbedaan yang signifikan antara hasil tes awal dan tes akhir pada kelompok II.

Dari hasil uji perbedaan yang dilakukan terhadap hasil tes akhir pada kelompok I dan kelompok II, diperoleh nilai $\mathrm{t}$ hitung $=2,6651$ sedangkan t tabel $=1,7613$. Berarti hipotesis nol ditolak, dengan demikian dapat disimpulkan bahwa setelah diberikan perlakuan, terdapat perbedaan yang signifikan antara hasil tes akhir pada kelompok I dan kelompok II. Karena sebelum diberi perlakuan kedua kelompok berangkat dari titik tolak yang sama, maka perbedaan tersebut terjadi karena perbedaan perlakuan yang diberikan.

Dengan demikian hipotesis yang menyatakan "ada perbedaan pengaruh antara metode latihan fartlek dan interval terhadap daya tahan (endurance) terhadap peserta didik dapat diterima.

2. Latihan interval memiliki pengaruh yang lebih baik dari pada latihan fartlek terhadap peningkatan daya tahan (endurance) terhadap peserta didik 
Kelompok I yang diberikan perlakuan metode latihan fatrlek memiliki nilai persentase peningkatan sebesar 2,62 \% . Sedangkan pada kelompok II yang diberikan perlakuan metode latihan interval memiliki nilai persentase peningkatan sebesar $5,64 \%$. Dengan demikian hipotesis yang menyatakan bahwa "latihan interval memiliki pengaruh yang lebih baik dari pada latihan fartlek terhadap peningkatan daya tahan (endurance) terhadap peserta didik, dapat diterima.

\section{SIMPULAN DAN SARAN}

\section{Simpulan}

Berdasarkan hasil penelitian dan hasil analisis data yang telah dilakukan, dapat diperoleh simpulan sebagai berikut:

1. Ada perbedaan pengaruh yang signifikan antara metode latihan fartlek dan interval terhadap daya tahan (endurance) pada peserta didik, $\left(\mathrm{t}_{\text {hitung }}=2,6651>\right.$ 1,7613).

2. Metode latihan interval lebih baik pengaruhnya daripada metode latihan fartlek terhadap daya tahan (endurance) pada peserta didik. Berdasarkan persentase peningkatan daya tahan (endurance) menunjukkan bahwa kelompok 2 (kelompok yang mendapat perlakuan dengan metode latihan interval) adalah 5,64 \% > kelompok 1 (kelompok yang mendapat perlakuan metode latihan fartlek) adalah 2,62 \%.

\section{SARAN}

Sehubungan dengan simpulan, maka disarankan hal-hal sebagai berikut:

1. Dalam memilih jenis latihan, khususnya untuk meningkatkan daya tahan (endurance) hendaknya memilih jenis latihan yang efektif dan optimal.

2. Dalam upaya untuk meningkatkan daya tahan (endurance) guru, peserta didik, dan pelatih dapat menggunakan metode latihan fartlek atau interval karena keduanya terbukti dapat meningkatkan daya tahan (endurance) walaupun metode latihan interval lebih baik pengaruhnya. 
3. Manfaat yang diperoleh guru, peserta didik, dan pelatih dalam melakukan penelitian ini, yaitu:

\section{a. Bagi Guru}

Penelitian ini bermanfaat bagi guru sebagai bahan masukkan untuk mengetahui cara meningkatkan kebugaran jasmani peserta didik supaya lebih berprestasi dalam bidang non akademik.

b. Bagi Peserta Didik : Penelitian ini bermanfaat bagi peserta didik sebagai cara untuk meningkatkan daya tahan (endurance) supaya dapat memiliki fisik yang bagus dan prima guna mendapatkan prestasi di bidang non akademik.

c. Bagi Pelatih

Penelitian ini bermanfaat bagi pelatih sebagai masukkan untuk membuat program latihan yang dapat meningkatkan kemampuan fisik para atletnya supaya dapat bersaing dan berprestasi serta seorang pelatih dapat memilih jenis latihan yang efektif dan optimal. 


\section{DAFTAR PUSTAKA}

Brown, R. L. (1996). Bugar Dengan Lari. Jakarta: Raja Grafindo Persada.

Carthy, A.M. (1995). Kiat Ramping dan Tetap Bugar Petunjuk Parktis untuk Hidup Sehat. Jakarta: PT Gramedia Pustaka Utama.

Giriwijoyo,Y.S., Santoso. (1992). Ilmu faal olahraga. Bandung: FPOK IKIP Bandung.

Hairy, J. (1989). Fisiologi Olahraga. Jakarta: Departemen Pendidikan dan Kebudayaan.

Handoyo, A. (2010). Bermain Futsal. Jakarta. Nobel Edumedia Rukan Graha Cempaka Mas.

Harsono. (1998). Coaching Dan Aspek-Aspek Psikologis Dalam Coaching: Jakarta. C.V Tambak Kusuma.

Irianto, D. P. (2002). Dasar Kepelatihan. Yogyakarta: FIK. UNY.

Irianto, D. P. (2004). Pedoman Praktis Berolahraga. Yogyakarta: FIK. UNY.

Ismaryati. (2011). Tes dan Pengukuran Olahraga. Surakarta: UNS Press.

Lhaksana, J. (2011). Taktik \& Strategi Futsal Modern. Jakarta: Be Champion.

Mulyono, M. A . (2014). Buku Pintar Panduan Futsal. Jakarta: Laskar Aksara.

Mulyono. (2010). Tes \& Pengukuran Pendidikan Jasmani Olahraga. Surakarta: UNS Press.

Pate, Rotella, \&Clenaghan, M.C. (1993). Scientific Foundationof Coaching. New York: Sounders College Publishing. Terjemahan.

Pate, Rotella, \&Clenaghan, M.C. (1993). Dasar-Dasar Ilmiah Kepelatihan. Terjemahan. Kasiyo Dwijowinoto. Semarang: IKIP Semarang Pers.

Purnama, S. K. (2010). Kepelatihan Bulutangkis Modern. Surakarta: Yuma Pustaka.

Sajoto, M. 1995. Peningkatan dan Pembinaan Kekuatan Kondisi Fisik Dalam Olahraga. Semarang: Dahara Priza.

Soegito. (1998). Teori dan Praktek Atletik Lanjut II. Surakarta. FKIP POK Universitas Sebelas Maret, Surakarta.

Soekarman, R. (1991). Energi dan Sistem Energi Predominan Pada Olahraga. Jakarta: KONI Pusat.

Sukadiyanto. (2011). Pengantar Teori dan Metodologi Melatih Fisik. Yogyakarta: FIK Universitas Negeri Yogyakarta. 